УДК: 811.163.41'367

DOI: $10.18485 /$ belic_slv.2016.1.ch14

\title{
Миливој Алановић \\ ЕВОЛУЦИЈА НАЧЕЛА СТРУКТУРНЕ ОРГАНИЗАЦИЈЕ РЕЧЕНИЦЕ У СРПСКОЈ ЛИНГВИСТИЦИ
}

\section{1. Увод}

Како реченица представља основну синтаксичку јединицу, сасвим је очекивано и да се питање њенога унутрашњег устројства наметне као један од централних теоријско-методолошких проблема у синтакси, без обзира на то о ком правцу или школи је реч. Развој синтаксе је обележила управо смена, или пак еволуција, начела структурне организације реченице, а она су се заснивала било на централности једнога члана реченице - субјекта или предиката, било на функционалносемантичкој дихотомији или двојству субјекта и предиката, односно одговарајућих синтагми. Ове развојне фазе у синтакси се очитују и у српској лингвистици, нарочито у радовима А. Белића, М. Стевановића, Љ. Поповића, П. Мразовић, В. Ружић и др.

Смена теоријско-методолошких парадигми је значила промену хијерархије међу реченичним члановима, али и повећање броја (релативно) аутономних реченичних чланова. Тако, примера ради, за А. Белића постоје само два реченична члана - субјекат и предикат, односно субјекатска и предикатска синтагма, при чему је субјекат реченични регенс. С друге стране, Љ. Поповић међу реченичне чланове убраја још и објекте, прилошке одредбе итд., док за субјекат и предикат истиче да су главни чланови реченице. И коначно, у вербоцентричном моделу који, пре свих, заступа П. Мразовић глагол је реченични регенс, док су сви остали чланови реченице, будући непосредно зависни од њега, његови депенденси или сателити.

Уз осврт на различите теоријске приступе у опису реченичне структуре, намера нам је да укажемо како на кључне развојне фазе српске синтаксе тако и на утицаје доминантних лингвистичких праваца на њу, посебно депенденцијалне граматике, што се не огледа само у прокламованим теоријским начелима, већ и у примењеној методологији, инвентару синтаксичких јединица, поступцима провере и сл. Задати циљ рада претпоставља утврђивање одговора на следећа питања: 
(а) Шта чини реченицу?

(б) Колико чланова има реченица?

(в) У каквом су међусобном односу реченични чланови?

(г) Који се поступци примењују у синтаксичкој анализи?

Одговори на ова питања пружиће нам увид у различите и често супротстављене приступе у синтаксичкој анализи, од којих су неки доминантно логичкосемантички или појмовни, док су други у основи структурни, међу којима ни до данас није пронађена адекватна равнотежа. Основ конфликта, очито, лежи у потреби да се логичкосемантичка и структурна организација реченице ускладе, доведу у функционалан однос. Зато историју лингвистике и прати упорна тежња да се раздвоје али и доведу у везу форма и значење, односно структура и њено значење, што се непосредно рефлектује на таксономију и на дефинисање, уопште поимање, основних синтаксичких категорија.

\section{2. Субјектоцентрична теоријска парадигма}

Најзначајније место у србистици, барем у првој половини двадесетог века, несумњиво припада Александру Белићу који је у теоријски најразрађенијем облику, не само за своје доба и не само у србистици, дао одговоре на сва питања која су од важности за синтаксу.

За А. Белића нема сумње да је реченица, иако не минимална, основна синтаксичка јединица јер је „најпростија и најмања говорна целина" (Белић 1998: 119). Овај став је од пресудне важности не само за одређивање предмета ове лингвистичке дисциплине већ и за одређивање инвентара синтаксичких јединица које се појављују у границама реченице, разуме се просте. Постављање реченице у центар синтаксичке анализе има вишеструк значај. Најпре, реченицом се указује на потпуност или завршеност каквог исказа, односно какве представе о неком стању ствари. Даље, синтаксичке јединице мање од реченице део су њене структуре, те се изван ње не могу ни појавити нити се могу интерпретирати. И коначно, реченица је хијерархијски устројена структура, а то значи да место једног елемента предодређује или условљава појава другог елемента. То, међутим, не значи да редослед чланова у реченици одражава њихову хијерархију. Напротив, хијерархија међу синтаксичким јединицама код Белића се заснива на њиховим појмовним или логичкосемантичким одликама, а не на оним структурним. 
Говорећи тако о структури реченице, Белић је изричит да се у реченици могу појавити само два члана, односно две синтагме - субјекатска и предикатска, а да реченица није ништа друго до веза та два обавезна појма, где један „господари” (субјекат) док му је други (предикат), „којим се нешто првом приписује”, непосредно „потчињен” (Белић 1998: 119). Иако двочлану организацију реченице налазимо и у теорији фразних структура, типичној за прву фазу развоја генеративне граматике (Филипи/Тевес 2010: 43; Диршајд 2012: 127), за Белића се ипак не може рећи да је генеративиста, а разлога су барем два. Белић, наиме, не трага за правилима извођења, или генерисања, фраза и реченица и, што је још важније, он међу овим двема синтагмама успоставља хијерархију, при чему увек оперише развојноисторијским, логичкосемантичким и појмовним критеријумима, те одбацује наслеђе из логике по ком се глаголу даје нарочит значај, мимо његове стварне улоге у реченици и у језику уопште (Белић 1998: 68). Штавише, Белић за предикат наводи да је субјекатска одредба, истина, одређене врсте (Белић 1998: 122), а способност да личним наставком идентификује лице узима као показатељ његове подређености у односу на субјекат (Белић 1998: 35).

Белићу је, све указује на то, најважнија појмовна организација реченице, што се види и на основу дефиниције основних реченичних чланова али и на основу дефиниције саме реченице. У његовом моделу најважнију улогу играју именице као „самосталне предметске речи” (Белић 1998: 460), док глагол представља несамосталну реч „јер радњу неко мора вршити" (Белић 1998: 552). Како именице заузимају позицију субјекта а не предиката - барем не оног глаголског, јасно је зашто се Белић опредељује за субјекат као централни члан реченице. Овај у основи позитивистички став може се, између осталога, бранити и чињеницом да је наш спољашњи свет 'саздан' од конкретних предмета, тј. од именица, а да су глаголи само релације које дате предмете доводе у везу.

Своју позицију Белић доста успешно брани када је реч о персоналним реченицама, али је заступање става о централности субјекта у случају имперсоналних реченичних структура доста проблематично. Истина, он се и ту ослања на логички или појмовни план реченице, или ситуације, тврдећи да се присуство непознатог субјекта („фактора”) подразумева или осећа, тачније „вршилац радње постоји, само је непознат. Без њега не би могло бити радње” (Белић 1998: 487).

Један од крунских Белићевих аргумената којим доказује првенство субјекта над предикатом јесте да се идентификовањем субјекта радња коју он врши подразумева - „Глагол је особина живих створова или каткада и предмета. И када констатујемо да се глаголска радња врши, 
осећамо и онога и оно што га врши” (Белић 1998: 549 ). Не можемо а да не приметимо да се правило предвидивости и предодређености допуна у депенденцијалној граматици везује управо за глаголе (Велке 1988: 41; Хелбиг 1992: 82-83; Агел 2000: 70; Велке 2011: 53). Наиме, када се узму глаголи типа блејати, мекетати, лајати итд., наравно у основном значењу, идентитет субјекатског појма је предодређен, а то су овца, коза и пас, док ако кренемо обрнутим путем, од појмова овца, коза и пас, тада се као контекстуални партнер ових именица у реченици не појављује нужно неки од наведених глагола већ и читав низ других, типа јестu, numu, спавати, лежати, трчати итд.

Тест предвидивости контекстуалних партнера нам показује како се једна специфична појава у језику може интерпретирати на различите начине. Белић, наиме, трага за општим одликама појмова, тако да је очито да у таксонимији прототипичних одлика овце важно место има блејање, пса има лајање а козе има мекетање. С друге стране, ако трагамо за елементима структурне организације реченице, онда свакако не можемо прихватити став да је предикат субјекатска одредба, па ма и посебне врсте, јер је у некој структури доминантан онај елемент који даје граматичку информацију о другим елементима (Ружић 2005: 478), односно без ког ни других елемената нема (Агел 2000: 70).

Белићу је концепт предвидивости допуна кључан и када је реч о месту објекта у реченици. Тако, у реченици Ја волим он реконструише неизречени, или засебном речју необјављени, али стварни и увек подразумевани објекат изван самог субјекта (Белић 1998: 256). Последње показује да за Белића тест испустивости не представља поуздан критеријум за разликовање допуна и одредаба, или додатака, што је постао преовлађујући став и у депенденцијалној граматици, али тек крајем прошлог века (Агел 2000). Ипак, и у овом случају Белићева дефиниција ових валенцијских јединица је у основи - семантичка. Наиме, одредбама се, каже Белић, „каква особина која је латентна у језичком потенцијалу речи - открива”, док се допунама „открива саставни део појма који је изван њега, али са којим дотични појам чини органску целину: орати земљу, сећи дрва, сећи тестером, орати ралицом итд." (Белић 1998: 129). Како то и последњи примери илуструју, Белић међу допуне, осим објеката, сврстава још и социјативни инструментал и инструментал средства (Белић 1998: 135), а свима њима је заједничко да се у реченици појављују у одређеној форми, што показује да, иако то у теоријском и методолошком смислу није до краја разрадио, Белић за допуне везује обележје сталности или предвидивости форме - укључује их у глаголску синтагму као њене зависне чланове, а најважније им је обележје зависна падежна фор- 
ма. Ипак, Белић не занемарује ни функцију падежних синтагми, те зато одредбене синтагме види као резултат функционалне транспозиције допунских синтагми, које неретко напуштају систем падежа и прелазе у друге категорије речи, нпр. придеве и прилоге (Белић 1998: 130, 157). Ово је отуда што је функција, после значења, „главна особина речи” (Белић 1998: 470), што стоји у директној корелацији са Тенијеровим ставовима да су за зависне чланове реченице резервисане две функције или улоге - актантна и сирконстантна (Тенијер 1969: 102), што одговара данас уобичајеној подели ‘зависних’ функција на допунске и одредбене.

\section{3. Полицентрична теоријска парадигма}

Главне црте Белићевог учења налазимо, у нешто измењеном облику, и код М. Стевановића (Стевановић 1979: 1-6), који такође полази од реченице као основне језичке јединице којом се изражава веза међу појмовима, те стога за реченицу истиче да је одликује мисаоно и интонационо јединство у ком се једним појмом нешто приписује другом појму, при чему наглашава двочланост реченичне структуре, не напуштајући тако Белићева начела синтагматске организације реченице.

Ипак, код њега примећујемо благу еволуцију начела о централности субјекта у реченици, који, иако преузима Белићеве ставове о посебности субјекта у реченици, готово истоветним речима дефинише и предикат, тврдећи да је он други главни члан реченице. М. Стевановић за субјекат тврди да је ,језгро реченице, њен основни део. То је самостална реч или група речи којом се означава појам (један или више њих), о коме се нешто казује, коме се нешто приписује. И од њега су, непосредно или посредно, зависне све остале речи у реченици" (Стевановић 1979: 23). С друге стране, дефинишући предикат, Стевановић наводи „да без приписивања чега основном члану и не може бити реченица, да предикат, према томе, у реченици има прворазредну улогу, и да се стога и он, ипак с правом, такође назива главним чланом најмање основне јединице језика. Предикат је, дакле, други главни члан реченице [...]” (Стевановић 1979: 34). Зато М. Стевановић субјекат и предикат обрађује посебно, одвајајући их од зависних чланова реченице, међу које сврстава одредбе и допуне, где међу последње примарно убраја објекте.

Можемо приметити да се код Стевановића између субјекта и предиката успоставља однос интердепенденције која се у основи своди на конгруентну везу међу њима, што је и другим истраживачима послужило као аргумент да се субјекту да посебан статус у реченици (нпр. Еромс 
2000: 184; Ајзенберг 2013: 283). У Стевановићевом приступу успоставља се равнотежа између ова два реченична члана, што значи барем две ствари: прво, значај предиката далеко превазилази значај одредби, које се у начелу одређују као факултативни чланови реченице или синтагме, и друго, ограничавање значаја субјекта у реченици за чије се управљачке способности може рећи да су врло ограниченога домета. Осим имплицитног одређивања реченице као полицентричне структуре, Стевановић је направио још један искорак, он не говори више о синтагмама, иако прихвата синтагматску организацију реченице, већ препознаје и друге чланове у реченици, пре свега прилошке одредбе и објекте као допуне. Овим је јасно да се двочлана, тј. синтагматска организација реченице лагано напушта, те да своје место уступа конституентском рашчлањавању реченице.

Попут Белића, и Стевановић покушава да разреши однос између допуна и додатака као зависних синтаксичких јединица, где за допуне, таутолошки, каже да допуњавају друге врсте речи од којих зависе, углавном глаголе или именске речи, а међу њима су превасходно објекти (Стевановић 1979: 74, 76). За објекте истиче да могу бити обавезно и необавезно укључени у реченицу, што показује да испустивост ни за Стевановића, као ни за Белића уосталом, није кључни критеријум за разликовање допуна и одредаба, већ је то, иако нигде експлицитно не наводи, њихова формална предодређеност. Ово је посебно упадљиво када разматра именске и прилошке допуне, нпр. субјекатски, објекатски и партитивни генитив и сл. Стевановић наводи да допуна мора имати падежно значење, док одредба има прилошко или придевско значење (Стевановић 1979: 84). Иако му је функционалносемантички критеријум кључан, он не заборавља ни формална обележја, те могућност да се одредбе замене прилозима или придевима, што јасно показује да је Стевановић имао на уму две ствари: сталност допунских форми и несталност оних одредбених.

Доследнији у конституентском рашчлањавању реченице је Љ. Поповић, који наводи листу реченичних чланова које дели у две групе: (а) главне, и (б) зависне (Станојчић/Поповић 2014: 235, 259). Међу главне чланове реченице Поповић убраја субјекат, као независни члан реченице, и предикат, како глаголски тако и копулативни, као централни и други главни члан реченице од ког зависе његове допуне (Станојчић/ Поповић 2014: 235, 237, 245), установљавајући у овој дихотомној вези, тј. у јединству субјекта и предиката реченично језгро, што је став који заступају још и М. Миновић (Миновић 1987: 31), П. Пипер (Пипер/ Клајн 2013: 280, 296) итд. С друге стране, међу зависне чланове реченице 
Еволуција начела структурне организације реченице у српској лингвистици 221

убраја објекте, прилошке одредбе, допунски предикатив и актуелни квалификатив. Поповићев модел указује на неколико важних појединости у поступку синтаксичке анализе, а оне се тичу разврставања реченичних чланова на главне и зависне, с једне стране, те даљу поткласификацију зависних чланова на допуне и додатке. Ипак, као потенцијално спорна у овој подели се могу окарактерисати барем три поступка, око којих не постоји општа сагласност у лингвистици, па ни у србистици:

(а) издвајање актуелног квалификатива као аутономног реченичног члана;

(б) раздвајање адвербијала у две супротстављене валенцијске класе - допуне и одредбе;

(в) несврставање предикативних допуна које комплементизују копулативне глаголе у реченичне чланове.

Као, само наизглед, најочитија недоследност чини се издвајање актуелног квалификатива као посебног реченичног члана (Станојчић/ Поповић 2014: 257), што се нарочито односи на примере где ова синтаксичка јединица ступа у конгруентну везу са субјектом или објектом, нпр. Дошла је уморна и Видео сам је уморну. Наиме, увођењем конгруентног актуелног квалификатива као новог члана реченице увећала би се базична валентност управног глагола, што ипак није случај. Било да је реч о субјекатском било о објекатском квалификативу, чини се сасвим утемељеним поћи од става да су у питању атрибути у оквиру субјекатске или објекатске синтагме, односно синтагми чије су главе одговарајуће именске речи (в. Беби 2009: 251, 255), што и конгруенција између субјекта и објекта, с једне, и актуелног квалификатива, с друге стране, потврђује (нпр. Дошао је уморан; Дошла је уморна; Видео сам га тужног; Видео сам је тужну и сл.). Уважавањем ових аргумената, овај тип актуелног квалификатива не би могао бити интерпретиран као зависни реченични већ зависни синтагматски члан (нпр. в. Еромс 2000: 211).

Више дилема изазива разликовање прилошких допуна и прилошких одредаба (Станојчић/Поповић 2014: 252), тачније критеријуми на основу којих се ова подела изводи, као и изједначавање реченичних функција и валенцијског статуса конституентских јединица. У основи поделе адвербијала на допуне и одредбе лежи критеријум испустивости (в. Хелбиг 1992; Агел 2000; Станојчић/Поповић 2014: 257), премда велике недоумице изазива питање шта се применом овог критеријума доказује. Без обзира на то да ли је реч о допунама или одредбама, адвербијали нису никада уведени као резултат јаке рекције глагола, тј. као формалноспецифичне јединице. Тако се у примеру Ана се налази испред куће 
/ на сајму / у школи / пред рестораном могу реализовати просторни адвербијали у различитим формама чија је једина специфичност што су семантички компатибилни са глаголом, односно што се њиховим испуштањем добија неграматична конструкција. Дакле, глаголу је потребан конкретизатор места, али то не мора бити формалноспецифична морфосинтаксичка јединица већ и деиктички прилог - my, тамо итд. То доказује да тзв. прилошке допуне нису резултат јаке рекције регенса те да се синтаксички и семантички идентично понашају као и остале одредбе, с том разликом да је њихово присуство у реченици - обавезно (в. Алановић 2012), што нам говори да је разлика међу једнима и другима у основи комуникативно-прагматичке природе - неки адвербијали су испустиви(ији) а неки неиспустиви, што важи и за објекте уз различите

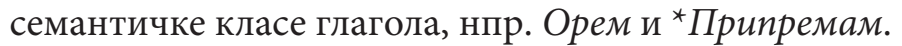

Ипак, највећи проблем у таксономији синтаксичких јединица јесте питање статуса предикатива, те уопште структуре сложених предиката.

Пратећи развој депенденцијалне граматике приметно је да је ово питање остало место спорења, али је преовладао став да су предикативи допуне (Еромс 2000: 205; Енгел 2009: 147; Мразовић 2009: 535). Шта ово подразумева? Ако је предикатив допуна, то значи да има статус реченичног члана, тако да субјекат и предикатив уз копулативни глагол, у примеру типа Ана је учитељица, у депенденцијалном стаблу заузимају исти хијерархијски ниво. Нпр.:

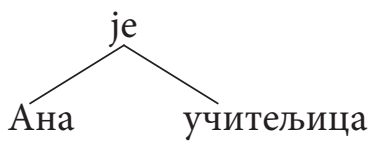

Било је покушаја да се предикативна именица или придев посматрају заједно са финитним глаголом као центар или језгро реченице (Велке 2011: 108), али се у том случају мора разрешити следећи проблем: како се предикативна јединица може прогласити непосредним регенсом у односу насубјекат. Сасвимјејасно дајенемогућеобјаснитидаименицаучитељица регира именицу Ана. С друге стране, како је могуће да реченично језгро чине две морфосинтаксичке речи, односно како то да две различите морфосинтаксичке јединице чине једну конституентску јединицу. На овоме месту треба, очито, указати на различите приступе овоме проблему - први је структурнограматички а други функционалносемантички. По првом, конструкција је учитељииа не може бити један реченични члан, док по другом је учительица јесте једна функционалносемантичка јединица. Међутим, функционалносемантичка перспектива омогућује 
Еволуција начела структурне организащије реченице у српској лингвистици 223

да се и други реченични чланови интегришу у састав предиката, при чему мислимо на бројне примере глаголских перифраза, попут оних у реченицама типа Издао им је наредбу да крену; Извршили су напад на гранични пункт; Обузела га је језа; Дрма га пубертет; Несанииа га данима мучи; Ушао је у дубоку старост итд. Иако се конструкције издао је наредбу, извриили су напад, језа је обузела, несаница мучи, ушао је у дубоку старост итд. интерпретирају као примери глаголских перифраза, тј. сложених предиката, у свим се случајевима ради о двочланим конструкцијама које, уз финитни глагол, чини још неки од његових аргумената - субјекат, објекат или адвербијални додатак (в. Алановић 2013а, 2013б).

\section{4. Вербоцентрична теоријска парадигма}

Први прави заступник депенденцијалног граматичког модела у србистици је Павица Мразовић, која је у теоријски и методолошки најразрађенијем облику изнела начела овог граматичког приступа (Мразовић 2009), у духу начела У. Енгела и његове (глаголско-)депенденцијалне граматике. Вербоцентрични модел устројства реченице подразумева да је финитни глагол регенс, док су сви остали чланови реченице зависни од њега, те представљају његове депенденсе или сателите (Мразовић 2009: 37). У овом моделу се субјекат не издваја као посебна допуна, већ заједно са осталим зависним реченичним члановима стоји на истој (у односу на

финитум нижој) хијерархијској равни унутар депенденцијалног стабла, нпр.:

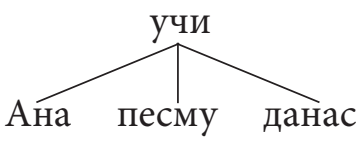

Као аргумент да субјекат не може бити главни конститутивни елемент реченице узима се појава да се ова допуна не јавља уз све глаголе (Мразовић 2009: 525). Осим тога, В. Ружић, која такође прихвата вербоцентрични модел реченичне организације, истиче да „глагол заузима средишње место у структурној организацији реченице јер од његове валентности, тј. опште способности да веже друге главне реченичне чланове, тзв. аргументе, зависи формирање основних структурних образаца и модела реченице” (Ружић 2005: 478), док промену хијерархијског односа између субјекта и предиката заснива на чињеници да финитни глагол „садржи податак о носиоцу ситуације” (Ружић 2005: 478). 
Већ се готово по традицији у овом лингвистичком правцу усталила пракса уредног разврставања сателита на две класе - допуне и додатке, што је, с једне стране, постало обавезним и препознатљивим делом његове појмовне и методолошке апаратуре, док је, с друге, (п)остало тачком спорења, коме се ни данас не назире крај. Основно питање које се овде намеће јесте да ли се могу, или уопште морају, сви зависни реченични чланови разврстати доследно у две аутономне групе јединица, односно колико су наведене групе јединица кохерентне. Одричан одговор на претходна питања у великој мери подрива доследност и поузданост примењених класификационих критеријума, што се види и код П. Мразовић, која, применом критеријума сталности форме и (нарочито) испустивости, међу допуне сврстава ситуитивне, темпоралне и неке каузалне адвербијале (Мразовић 2009: 2009: 532-535), на које се, међутим, критеријум сталности форме једноставно не може применити.

\section{5. Закључак}

Основне развојне тенденције у синтакси, видели смо, дају се пратити и у србистици, а оне се у основи своде на замену субјектоцентризма вербоцентризмом, с једне стране, односно на замену моноцентризма полицентризмом. Слеђење савремених лингвистичких токова, или активно учешће у њима, међутим, донело је и бројне теоријске и методолошке проблеме, на које ни србистика није остала имуна нити је успела да, за сада, да задовољавајуће и општеприхваћене одговоре.

Зато је један од задатака савремене лингвистике, па, наравно, и србистике, прецизније одређивање односа између допуна и додатака, уз стабилизацију коначног броја реченичних чланова, што је могуће учинити на два начина: (а) формулисањем доследно применљивих структурних критеријума класификације, и (б) ублажавањем оштре границе међу допунама и одредбама, или додацима, те формирањем континуума који ће омогућити блажи прелаз из једне у другу категорију (в. Алановић 2012).

Као што смо у више наврата показали, тест испустивости је погоднији за поткатегоризацију унутар одређене класе граматичких, или тачније валенцијских јединица него за успостављање границе међу њима. Зато се чини да критеријум формалне специфичности, или падежне форме у Белићевом и Стевановићевом смислу, обезбеђује поузданији основ за утврђивање валенцијског статуса неке зависне синтаксичке јединице, док критеријум синтаксичке обавезности омогућује да се формира категорија на прелазу између допуна и одредаба/додатака, као што су нпр. адјункти (в. 
Еволуиија начела структурне организације реченице у српској лингвистиии 225

Алановић 2012), односно да се успостави скала састављена од посебних, преко типичних до атипичних јединица (в. Алановић 2014), чиме би се ублажио дубок јаз међу допунама и додацима, с једне стране, те формирала прелазна категорија јединица које немају обележје формалне специфичности али показују висок степен синтаксичке обавезности.

\section{ЛИТЕРАТУРА}

Агел 2000: Vilmos Àgel, Valenztheorie, Tübingen: Gunter Narr Verlag.

Ајзенберг 2013: Peter Eisenberg, Der Satz. Grundriss der deutschen Grammatik, Band 2, Stuttgart - Weimar: Verlag J. B. Metzler.

Алановић 2012: Миливој Алановић, „Допуне и додаци: између обавезности и испустивости", Годишьак Филозофског факултета у Новом Саду, XXXVII/2, 145-162.

Алановић 2013a: Миливој Алановић, „Типични структурно-семантички модели глаголских перифраза са глаголима просторно-мобилних односа", Зборник Матище српске за филологију и тингвистику, 56/2, 39-59.

Алановић 2013б: Миливој Алановић, „Елементи структурне и семантичке организације глаголских перифраза”, Српски језик, XVII/1, 193-212.

Алановић 2014: Миливој Алановић, „Валенцијски статус и хијерархија синтаксичких јединица", Годишғьк Филозофског факултета у Новом Садy, XXXIX/2, 9-28.

Беби 2009: Leonard H. Babby, The Syntax of Argument Structure, Cambridge: CUP.

Белић 1998: Александар Белић, Општа лингвистика, Изабрана дела Александра Белића, том 1, Београд: Завод за уџбенике и наставна средства.

Велке 1988: Klaus Welke, Einführung in die Valenz- und Kasustheorie, Leipzig: Bibliographisches Institut.

Велке 2011: Klaus Welke, Valenzgrammatik des Deutschen. Eine Einführung, Berlin - New York: Walter de Gruyter.

Диршајд 2012: Christa Dürscheid, Syntax. Grundlagen und Theorien, Göttingen - Bristol: Vandenhoeck \& Ruprecht - CT.

Енгел 2009: Ulrich Engel, Syntax der deutschen Gegenwartssprache, Berlin: ESV.

Eромс 2000: Hans-Werner Eroms, Syntax der deutschen Sprache, Berlin - New York: Walter der Gruyter.

Миновић 1987: Milivoje Minović, Sintaksa srpskohrvatskog/hrvatskosrpskog književnog jezika za više škole. Rečenica, padeži, glagoli, Sarajevo: Svjetlost. 
Мразовић 2009: Pavica Mrazović, Gramatika srpskog jezika za strance, Novi Sad Sremski Karlovci: Izdavačka knjižarnica Zorana Stojanovića.

Пипер/Клајн 2013: Предраг Пипер, Иван Клајн, Нормативна граматика српског језика, Нови Сад: Матица српска.

Ружић 2005: Владислава Ружић, „Проста реченица као синтаксичка целина”, у: Предраг Пипер и др., Синтакса савременога српског језика. Проста реченица, Београд: Институт за српски језик САНУ - Београдска књига - Матица српска, 477-571.

Станојчић/Поповић 2014: Живојин Станојчић, Љубомир Поповић, Граматика српског језика за гимназије и средюе школе, Београд: Завод за уџбенике.

Стевановић 1979: Михаило Стевановић, Савремени српскохрватски језик II, Београд: Научна књига.

Тенијер 1969: Lucien Tesnière, Éléments de syntaxe structurale, Paris: Éditions Klincksieck.

Филипи/Тевес: Jule Philippi, Michael Tewes, Basiswissen: Generative Grammatik, Göttingen: Vandenhoeck \& Ruprecht.

Хелбиг 1992: Gerhard Helbig, Probleme der Valenz- und Kasustheorie, Tübingen: Max Niemeyer Verlag.

Milivoj Alanović

DIE ENTWICKLUNG DER PRINZIPIEN DER STRUKTURELLEN ORGANISATION DES SATZES IN DER SERBISCHEN SPRACHWISSENSCHAFT

Zusammenfassung

Mit dieser Arbeit wollten wir auf unterschiedliche theoretische und methodologische Zugänge zur Beschreibung der Organisation des Satzes in der serbischen Sprachwissenschaft in der zweiten Hälfte des Zwanzigsten Jahrhunderts hinweisen. In dieser Periode sind zwei grundsätzliche Phänomene zu bemerken: erstens, der polyzentrische Zugang hat den monozentrischen Zugang ersetzt, und zweitens, das Subjekt als Zentrum des Satzes wurde durch das Prädikat abgelöst, was zu der Annahme der strukturalistischen Paradigma weiter führte. Außer den Rückblick auf die Prinzipien der strukturellen Satzorganisation, haben wir auf die Kriterien und Probleme der Satzanalyse zurückgewiesen, wobei wir uns besonders mit der Unterscheidung von Ergänzungen und Angaben beschäftigt haben. 